Island Studies Journal, Vol. 11, No. 1, 2016, pp. 133-144

\title{
A man and his island: The island mirror in Michael Crummey's Sweetland
}

\author{
Laurie Brinklow \\ University of Prince Edward Island, Canada \\ brinklow@upei.ca
}

\begin{abstract}
Between 1946 and 1975, dozens of islands and outports in the Canadian province of Newfoundland and Labrador were abandoned as part of a government resettlement policy. Families and communities were torn apart, and a culture and way of life that revolved around the fishery changed irrevocably. The practice, which continues to this day, has been well documented, particularly by artists and writers. Michael Crummey's 2014 novel Sweetland is a recent iteration. The relationship between humans and place is complex: on an island, with compressed space and a very real boundary that is the ocean, emotional attachments to one's place are often heightened and distilled. What happens when a person is displaced from his or her island; when bonds of attachment are severed and one's mirrored double is destroyed? Sweetland offers a fictional lens through which we see an example of a mirrored relationship between an island protagonist and his island setting. Exploring themes of attachment to place, and what Barry Lopez calls a "storied" or "reciprocal" relationship with the land, this paper examines what happens to a man when confronted with leaving an island he knows as deeply as his own body and soul; and how the island reacts.
\end{abstract}

Keywords: island identity, islandness, Michael Crummey, Newfoundland, resettlement, Sweetland

(C) 2016 - Institute of Island Studies, University of Prince Edward Island, Canada

\section{Introduction}

Identity is rooted in strong connections to place. And because, on an island, the place is a "singular geographic situation" (Weale, 1991, p. 82), "split off" and defined from the mainland, it is conducive to its inhabitants knowing its edges and all that is held within the bounds of the island as intimately as their house, their bodies, or their psyches. If geography is, as Yi-Fu Tuan (1971, p. 81) writes, a "mirror reflecting and revealing human nature and seeking order and meaning," then, through an interdisciplinary Island Studies lens grounded in phenomenology, an island can be seen as a mirror with an emphatic frame: the liminal space that widens and narrows with the ebb and flow of the tides. Within that shape-shifting frameedge, identity is distilled, or "articulated by compression" (Baldacchino, 2013), with perhaps stronger than usual ties that bind the island's inhabitants to their place. Because of its singularity, it is possible to hold an island in one's imagination, to get one's head, and heart, around it. As Tuan goes on to say (p. 270), "Geography is a mirror revealing the essence of human existence and human striving: to know the world is to know oneself."

Identity is also rooted in culture, a way of living in the world. Culture and spatiality are inextricably linked: storytelling, crucially, functions as an important medium through which that link is forged. Culture and identity find their voice in story: stories that are carried generationally, and strengthened in the retelling. "Eventually," writes Barry Lopez (1996, p. 


\section{Brinklow}

4), "the landscape inhabits $u s$, and its accumulated stories and memories become part of our collective narrative."

And if one applies the literary studies concept of mimesis, where the real world is imitated in art and literature, the mirror becomes significant on yet another level. The novel mirrors in fictionalized form a phenomenon that has happened, and continues to happen, on the islands and outports of Newfoundland; in this narrative, art imitates life. Within the geographical frame of the island, story and landscape, literature and geography, intersect on many levels to create a rich weave that places the novel alongside other Newfoundland novels in the island literature canon.

This paper, then, is about the bond between story and place in a 2014 novel called Sweetland by Newfoundland and Labrador author Michael Crummey, and how, in the retelling, story and place, too, become a "singular geographic situation" through the central character of Moses Sweetland. The novel is set on a fictional island off the island of Newfoundland, which is located in the North Atlantic off Canada's east coast; this island-offan-island is one about to lose its identity, erased from the map, as its inhabitants are forced to abandon it. Together, the character of Moses Sweetland and the island of Sweetland offer readers a study in islandness. What is to be learned about islandness and island identity through the character of Moses Sweetland? What is to be learned about Moses Sweetland and thus humans' connection to islands - by studying this island? In the end, while attachment to one's island may be stronger than other geographies, ultimately the hold of humans on their place - and place on their humans - is tenuous at best, particularly as more and more islands are resettled due to forces beyond islanders' control.

\section{The Newfoundland story}

First, the story behind the real place: the province of Newfoundland and Labrador. Comprising $405,212 \mathrm{~km}^{2}$, of which $111,390 \mathrm{~km}^{2}$ is the island of Newfoundland and the rest is Labrador on the mainland of Canada, the province has a rich and complex history. Inhabited first by the Inuit and Innu, then the Beothuks, the island was eventually settled by Europeans after John Cabot claimed it for England in 1497. Sustained primarily by its fishery, Newfoundland was known as Britain's oldest colony until it became a province of Canada in 1949. Newfoundland and Labrador follows the general rule of islands being peripheral to their mainlands (i.e., Canada), but, in the case of NL, mainland Labrador is considered to be peripheral to the island, with St. John's the centre of power. This unusual power dynamic makes for feelings of inferiority/superiority that mirror those of the province with Canada: a complex and nuanced relationship which itself is worthy of further study. However, because this paper focuses on islands, and islands off islands, I shall simply refer to the island portion of Newfoundland and Labrador by its name, Newfoundland.

Most Canadians would agree that Newfoundland is different: it has that "Newfoundland thing" that Michael Crummey has written about elsewhere (2004, p. 20). He calls this instinctual feeling an "inexorable gravitational pull ... elusive, ephemeral, and barely definable when we try to say exactly what it is and how it shapes us." Recent Newfoundland import, writer Stan Dragland (2012, n.p.), calls this "thing" an "imponderable," echoing the Maine Island Institute's Philip Conkling (2007, p. 191) when he calls "islandness" "a metaphysical sensation" that islanders know instinctively but cannot put into words. 
While there can be "no singular Newfoundland character" (Chafe, 2003, p. 323), for many Newfoundlanders, their sense of identity has roots firmly planted in their islandness, since so many of their stories are a result of being surrounded by the cold waters of the North Atlantic. Newfoundland has been compared to Tasmania, what Pete Hay (2006, p. 27) has called a "psychological sink" through which the mainland pours its ills. There can be sensed a simultaneous sense of inferiority and superiority amongst some of Newfoundland's people, and, with it, a longstanding grievance that Newfoundlanders have been wronged (Johnston 2009, pp. 22-23). Some view that Newfoundland's history is permeated by "a contemporary sense of loss, the sense that Newfoundland has crossed a definite cultural and historical threshold into an uncertain future, leaving behind a way of life that defined the province for centuries" (Wyile, 2011, p. 194). Others feel that Newfoundlanders harbour a "desire for a noble and triumphant past that never was" (Chafe, 2003, p. 342), for what many believe "could have been, if only" (Chafe, 2003, p. 332). Still others say that Newfoundlanders are "haunted" by their history, "trapped by it, forced to endure seemingly endless cycles of economic failure and social misery" (Bannister, 2003, p. 126). Whatever one believes to be the reason, or the outcome, identity in Newfoundland is strong and palpable, much of it stemming from its "singular geographic situation."

There are markers in the island's history that contribute to that sense of grievance and loss, of being haunted by their history: the extinction of the Beothuk in the 1800s, which represents "the fundamental loss in Newfoundland's history: the originary moment when what could have been was separated from what is" (Chafe 2004, p. 93); maritime disasters from shipwrecks to sealing disasters to the 1982 sinking of the Ocean Ranger oil rig; grinding poverty from a feudal system based in the fishery's "truck system" whereby fishers traded their fish for goods and were forever indebted to the merchant class (Cadigan, 2009); having the Newfoundland regiment virtually wiped out at the Battle of Beaumont Hamel during the First World War; being the only colony in the world to give up its independence - or, as some would say, "selling out" - without bloodshed when it became a province of Canada in 1949 after a referendum that divided families and communities. The collapse of the cod fishery in 1992 was a tipping point: an entire culture based on the fishery collapsed along with it.

Well before the end of the cod fishery, however, the province's first premier, Joseph Smallwood, the driving force behind Confederation with Canada, enacted several policies to attempt to modernize the province, to bring Newfoundlanders into the twentieth century, as it were. One of them was "resettlement." Between 1946 and 1975, dozens of outports, including islands, were abandoned as part of the provincial and federal governments' resettlement policy that saw over 28,000 people removed from 307 outport communities (Maritime History Archive, 2012: n.p.). Resettlement was carried out ostensibly to avoid providing these remote places with services such as transportation, electricity, health, and education. At the same time, new industrial "growth centres" were being created in the centre of the island to diversify the economy and lessen reliance on fish. Community and kinship webs were changed irrevocably as resettlement hauled people - many of whom hauled their houses with them into the industrial world of the twentieth century, leaving, for many, grief and loss in their wake. The "seamless progression of time [was] snapped," says Hay (2006, p. 33), leaving many to suffer the loss of their homes, their land, their livelihoods, their communities, their identity. Indeed, as curator Bruce Johnson (2001, p. 9) writes in his introduction to a book of photographs depicting derelict buildings on several resettled islands, the Resettlement Program "marks a psychic boundary between two countries [Newfoundland and post-1949 Canada] ... 


\section{Brinklow}

Resettlement is a subject deep-seeded within the collective (un)conscious of the place." Perhaps not surprisingly, as provincial governments attempt to balance their budgets by rationalizing services in remote communities, the policy of resettling outport communities continues to this day. Indeed, in 2014 when Sweetland was released, the story of Little Bay Islands in Notre Dame Bay off the north-central coast of Newfoundland was in the news; residents were divided on whether to take the government's offer of $\$ 250,000$ per family to resettle their community (Sherren, 2014, n.p.). Crummey says he had not heard this particular story when he was writing the novel, but while travelling around Newfoundland and Labrador he had certainly heard about communities that decided to take the government buyout and move, complete with "stories where all but one person signed on the dotted line" (Bisonette, 2014, n.p.).

\section{The man who loved his island}

This sense of loss has been documented in academic articles and books (e.g., Chafe, 2010; Johnson, 2001; Kelly \& Yeoman, 2010; O'Flaherty, 1975), in art and music (e.g., Blackwood, 1979; Flaherty, 2012; Walden, 2001), in poetry and fiction (e.g., Dalton, 1993; Johnston, 2006; Rogers, 1984; Steffler, 1985). One of the latest iterations is the novel, Sweetland. The novel's protagonist, Moses Sweetland, is an irascible old codger, eccentric to the core. Except for a brief stint when he goes to work in Toronto with his friend Duke Fewer - and has an industrial accident that leaves him disfigured and unable to father a child - he has lived on the island all his life; indeed, his intention never to leave is the primary plot driver. Even though his tiny community of Chance Cove is a tight-knit weave of complex relationships with family and friends, Moses finds himself in an uneasy dance with his fellow islanders (living and dead); he is, in effect, islanded in more ways than one: psychologically, emotionally, and societally, as well as geographically. He is haunted by the death of his brother, and the loss of Effie, the woman he would have married had he not been disfigured and rendered impotent. Indeed, for many years he was the only person on the island who could tolerate her sons, the disreputable Priddle boys, who would return occasionally from working out west to their cabin in the woods. For most of his life, his most intimate relationships are with the land. He knows every nook and cranny, headland and raggedy gulch, as well as the winds and the tides; to leave would be to lose his place in the world, and he would rather sever ties with his family and friends than be forced to leave. Now in his 70s, he fishes and gardens, and in the first part of the novel watches over his great-nephew Jesse who has been diagnosed on the autism spectrum. He describes Jesse as he could have described himself had he looked in the mirror: "stranded on the island of his own peculiar self, that he'd never find a soul fit for his eccentric way in the world" (Crummey, 2014, p. 271).

Sweetland the island is a fictional island off Newfoundland's southeast coast, close to the French islands of St. Pierre et Miquelon. It was named for Moses Sweetland's ancestors, who had been the first family to fish and live there. Off of Sweetland can be found the even longer-abandoned Little Sweetland (similar to the real-life Fogo Island and Little Fogo Island off the north-central coast of Newfoundland). Michael Crummey notes that the inspiration for the island itself came from a real abandoned island, Baccalieu Island, in Conception Bay; it, too, has an abandoned lighthouse and keeper's house. Mirroring the real-life Grey Islands, where a herd of caribou was moved after the people were moved off, a herd of buffalo were transported to the fictional island of Little Sweetland "to determine there was no disease risk 
to local animals, after which the herd was meant to be introduced to the larger island of Newfoundland. Though that step was never taken" (Crummey, 2014, p. 36). The watery frame of the ocean's barrier creates ideal laboratory conditions for such experimentation on Little Sweetland, even as it becomes a watery grave for one buffalo that panics and drowns while being transported to the island.

Sweetland the man is a fisher, and when the cod fishery collapses in 1992 he becomes the lighthouse keeper until automation makes him redundant. In the novel, Sweetland the island is about to be made redundant, too: just as the buildings and fields return to nature, the modern world is overgrowing the island. As Moses Sweetland thinks, "The whole place was going under, and almost everyone it mattered to was already in the ground" (Crummey 2014, p. 92). He notes later in the narrative,

There was a new world being built around him. Sweetland had heard them talking about it for years on the Fisheries Broadcast: apocalyptic weather, rising sea levels, alterations in the seasons, in ocean temperatures. Fish migrating north in search of colder water and the dovekies they'd relied on to survive here suddenly useless. The birds and their habits were being rendered obsolete, Sweetland thought, like the VHS machines and analog televisions dumped on the slope beyond the incinerator. Relics of another time and on their way out (Crummey, 2014, p. 277).

Even though electricity arrives on the island in the early 1970s, and Moses has a computer and the Internet through which he plays online poker and Skypes with Jesse who lives just down the hill, most of the island's young people have left to find work or pursue their education; for them, leaving is the road to a better life. Because of the depopulation, the government offers all its aging residents a lucrative package to leave, with the codicil that not one person stay behind. Moses is the last holdout, receiving threats in notes hidden in his kitchen, or having his snares vandalized and the rabbits they had caught brutalized. But by the end of the first half of the novel he signs, just to please everyone; but he has secretly made up his mind to stay. He gathers up food and supplies (though forgets toilet paper and eventually has to raid his friend Queenie's Harlequin Romance collection), fakes his death, and hides out until "the final few residents ... left on the last ferry run and the place was officially erased from the map" (Crummey 2014, p. 163). Sweetland thought there'd be a send-off, "A chance to drink the island under before surrendering it for good" (Crummey 2014, p. 163), but his neighbours just trickled away, leaving him alone on the island. After all, how can he leave, he thinks, so very "certain of the place he came from? He'd always felt like it was more than enough to wake up here, to look out on these hills. As if he'd long ago been measured and made to the island's exact specifications" (Crummey 2014, p. 280). ${ }^{1}$ The island and the man fit together like a hand and glove.

\section{The castaway}

The second half of the book becomes a Robinsonade, where Moses follows the pattern of castaway narratives begun with the novel, Robinson Crusoe: surviving by exploiting the

\footnotetext{
${ }^{1}$ This line is reminiscent of the exactitude of island knowledge suggested in the first stanza of Prince Edward Island poet Milton Acorn's poem "The Island" (2002, p. 53): "Since I'm Island-born home's as precise / as if a mumbly old carpenter / shoulder-straps crossed wrong / laid it out / refigured to the last three-eighths of shingle."
} 


\section{Brinklow}

island's resources and what others have left behind, and relying on his stubbornness and inner resolve to survive. "Friday" or "Wilson" (from the 2000 movie Cast Away with Tom Hanks) is represented in a little shih tzu named Smut; whom Sweetland renames Mr. Fox and whose wily presence scares the bejesus out of him before he realizes the ghostly creature vandalizing his traps is his friend Loveless's lapdog who has jumped ship just before the last boat leaves. Like Robinson Crusoe, at one point Sweetland thinks of himself as "the king of the world ... though he never spoke the words aloud" (Crummey, 2014, p. 197).

Sweetland had "expected the place to feel larger with everyone gone ... echoing and unfamiliar, caverned with absence. But it seemed smaller and strangely intimate, as though it had shrunken down to fit his solitary presence" (Crummey, 2014, p. 194). But "now and again he was blindsided by an apocalyptic loneliness he was afraid he might be unequal to. As if he was the only living creature on the face of the earth" (Crummey, 2014, p. 197). He watches himself disappear into the photo of his Uncle Clar: "Saw the outline of himself superimposed on the ancient picture there, a ghostly image hovering in the background, as if he was a second exposure on the same strip of film. A figure bled of detail and substance, so that all the world showed through him. Moses Sweetland. This is he" (Crummey, 2014, p. 305). Like Sweetland the island, Sweetland the man is being erased from the world.

As time goes on, and winter sets in, life alone on the island becomes increasingly challenging: both physically and mentally. "In short," as a reviewer in The Globe and Mail (2014) writes, "death is coming for Sweetland, man and isle." Author Michael Crummey says he was not consciously aware of it when he was writing the book, but when he looks back, he sees that the biggest influence on the novel was watching his father face up to the cancer that killed him in 2002 . He is quoted as saying,

It wasn't until I had finished the book that it struck me that what Moses goes through, particularly in the second half of the novel, has a lot of similarities to what a person facing a terminal illness goes through. And it became clear to me then that the biggest influence on what happens to Sweetland and on the trajectory of the novel as a whole was watching my dad fight cancer, and then die of it. And although the book, on the surface, is about resettlement, in many ways I would say that what it's really about is mortality and what the way we face that mortality says about us as people (Robinson, 2015, n.p.).

What Moses experiences is a loss of life and a loss of place, resulting in a profound sense of what geographer Edward Relph (1996) calls "placelessness," a state of not-belonging that can demoralize or even incapacitate people who find themselves in a non-place-based, mediatized, world. In contrast to being emplaced in a community or embedded in a landscape one knows as intimately as one knows his or her body, loss of place can leave a person ungrounded, disembodied, unhinged. To that end, Moses is acutely aware that he might be descending into madness,

He held to what he'd chosen and managed to make a sort of peace with the bizarre incidents that had become a feature of his days, accepted the fact that some of the world he lived in couldn't be found on a map. A crazy person wouldn't be capable of separating the strangeness from the rest of his life, he thought, of settling in the midst of 
it. But he allowed it was possible that all crazy people thought that way (Crummey, 2014, p. 243).

Indeed, as the winter progresses, Sweetland begins to think that he and the island have actually become invisible. He goes to the shore, hoping "he might catch a glimpse of a container ship swinging wide for the eastern seaboard of the States, some evidence of the world rumoured beyond the island's ark. But there was only the endless conveyor belt of the waves ticking toward the shoreline" (Crummey, 2014, p. 273). He listens to the radio weather forecasts, "trying to match them to the conditions outside, though there wasn't a single reliable detail in the announcements. As if the island had drifted into its own latitude, beyond the reach of the CBC's meteorologists" (Crummey, 2014, p. 293). Later, he notes "the extended lull in the world he was observing. That there hadn't been a sign of a living creature in all the time he'd sat there. Even the gulls seemed to have disappeared. He'd grown accustomed to silence and stillness in his months alone. But the absence out there seemed of a different order altogether" (Crummey, 2014, p. 294).

Time passes and Sweetland the island starts to haunt Sweetland the man: first with lights on in his friend Queenie's window, then with music that blares from the church to guide him back into the cove when he is stranded in the fog. There are the inexplicable moves on the chess board left behind in Duke Fewer's barbershop. At one point when he is on the brink of starvation, he recovers a cod the size of a goat, which should have been rotten but was as fresh as if just caught. He begins to see himself as a "lunatic geriatric holed up on his own out there. Losing his frigging mind" (Crummey, 2014, p. 231). But if one accords agency to place, as exemplified in Lopez's words (1996, p. 11),

If you're intimate with a place, a place with whose history you're familiar, and you establish an ethical conversation with it, the implication that follows is this: the place knows you're there. It feels you. You will not be forgotten, cut off, abandoned.

The island wills Sweetland to continue, to survive; the island rescues him, keeps him company, brings him food when he is most desperate, again echoing Lopez (1996, p. 12) when he writes about forming an "ethical unity [with the place]... an intimate reciprocal relationship that will feed you in some way."

Most nights, to prevent himself from disappearing altogether into insanity, Moses

... pictured a map of the island and set about naming every feature and landmark from the south-end light to Chance Cove and on to the Fever Rocks, before he did the same thing along the lee side. The litany started at the Mackerel Cliffs and went from there to Pinnacle Arch, to Lunin Rock, the Devil's Under-jaw, the Flats, Murdering Hole, Tinker Cliffs, Old Chimney, Gannie Cliff Point, Wester Shoals, Mad Goat Gulch, Upper Brister, the Founder. He took his time, being careful to include as much detail as possible, as though the island was slowly fading from the world and only his ritual naming of each nook and cranny kept it from disappearing altogether (Crummey, 2014, p. 239). 


\section{Brinklow}

In integrating ideas of perception of space with the way humans map it mentally, Kevin Lynch (1960, pp. 126-127) writes how,

... the named environment, familiar to all, furnishes material for common memories and symbols which bind the group together and allow them to communicate with one another. The landscape serves as a vast mnemonic system for the retention of group history and ideals. Every detail of the countryside is a cue for some myth, and each scene prompts the recollection of their common culture.

Thus, in naming each rock and tickle, Sweetland keeps the island alive; as Lynch (1960, p. 127) says, he "vivifies it, and thereby adds to the depth and poetry of human experience." But, in the end, Sweetland "managed to make a sort of peace with the bizarre incidents that had become a feature of his days, accepted the fact that some of the world he lived in couldn't be found on a map" (Crummey, 2014, p. 243). In the novel's final pages, Sweetland describes the map to which he had added a

... long list of fanciful harbours and coves and islands and straits he'd pencilled around the coast... Where he expected to see Sweetland there was nothing but blue water. And Little Sweetland beside it the same. The names he'd written across the islands were gone. He thought Keith might have erased them, but even the ink outlines the names had been printed over were missing from the map. As if he'd only imagined seeing them there... He folded the map along the creases and set it in the cold firebox of the stove. He struck a match and dropped it in, watched as the paper curled in the heat, the edges charring black and disappearing in the travelling flame (Crummey, 2014, p. 317).

In this last symbolic gesture, the map was gone, so was he, and so was the island.

$[\mathrm{He}]$... stepped into the still air, into the cavernous quiet of the cove. He walked along the back of the property and up beyond the new cemetery, away from all he'd ever known or wanted or wished for. At the King's Seat he turned to look down on the water and there was nothing below but a featureless black, as if the ocean was rising behind him and had already swallowed the cove and everything in it (Crummey, 2014, p. 317).

Readers cannot help but speculate when Sweetland the man actually dies. Is it at the end of the novel's first half, when he is left clinging to the lighthouse keeper's ladder at the bottom of the cliff holding his nephew Jesse's battered body, leaving the second half, the Robinsonade, to be read as magic realism? Or is it when Sweetland sees the ghosts of his ancestors as he is returning to his house after searching for his missing dog, Mr. Fox? Sweetland sees

... hundreds of them standing on the headlands. All clustered close to the cliffs of the Fever Rocks, as many people as ever lived in the cove, he guessed, and not a sound among them. All facing the ocean where intermittent light stirred the blackness. A pale glow about the unlikely congregation though the moon was down, each figure silhouetted against the night sky. An air of watching about them so palpable that Sweetland held his breath as he watched (Crummey, 2014, p. 264). 
Or is it when his fever breaks and he finds that the dog was not missing after all? Or is it at the end of the novel, when the Priddle boys return to the island, and he thinks he is rescued, but when he awakens feeling rejuvenated from the soup they have fed him he joins the "press of silent figures with their faces turned to the open sea... resigned and expectant... their eyes on the fathomless black of the ocean. Sweetland anonymous among that congregation" (Crummey, 2014, p. 318)? In the end, his death is like the island's, disappearing when its people start to leave, when it is no longer remembered. It is no wonder that, in Crummey's hands, the character of Moses Sweetland, surrounded by so much of the island's past and a landscape so haunted by characters and stories, should disappear into the crowd of all those who had lived before him. As Crummey (in Isaacs, 2015, n.p.) has said,

People's lives here are intimately tied up with the place itself. It's difficult to separate those strands. And because of that, there is something in Newfoundlanders' connection to this place that seems otherworldly. I think it has something to do with the intertwined nature of the culture and the landscape. It's always been a difficult place to make a go of it economically, and the fishery is an incredibly dangerous occupation. It feels as if people's relationship to the world they live in here is heightened by the extremes of the place.

With these words, one is reminded once again of the distilled nature of island living.

\section{Endings}

One can feel nostalgic for a passing way of life such as the life Moses Sweetland once had on Sweetland the island, but at the same time one cannot be sentimental about the poverty, the extremes, the early and seemingly senseless deaths, the sheer difficulty of living on a remote Newfoundland island. As one reviewer (Robinson, 2015, n.p.) notes,

These places are where the province's history started, where its culture runs deepest, so we might expect resettlement plans to be wildly controversial. But they're not: those fishing villages all grew up because of cod, and cod is so close to extinction that the 1992 ban on fishing for it still hasn't been lifted. Newfoundlanders, buoyed by an offshore oil boom which is pumping unprecedented wealth into their capital, St. John's, seem to have grown resigned to outports slowly disappearing from the map.

Says Crummey (in Bisonette, 2014, n.p.): "Those places were there solely because it was close to the cod fishing ground and outside of that, there's not a lot to recommend these spots." The impermanence of life on an island in the North Atlantic is mirrored in the impermanence of the islands themselves, an object lesson as more and more islands are abandoned, not just because of economic upheavals beyond the control of islanders, but also rising sea levels similarly beyond their control. Like his previous novels and poetry that are set in his home province of Newfoundland and Labrador, Crummey continues to engage in issues that explore the mysterious Newfoundland "thing" that constitutes Newfoundland identity, yet contribute to the discussion of Newfoundland's place in a post-colonial world which requires "a difficult negotiation of historical nostalgia and essentialist conceptions of predetermination" (Sugars 2010, p. 31). 


\section{Brinklow}

In Sweetland, the line between the real world and the otherworldly, between life and death, begins to blur and eventually disappears altogether. As one reviewer has written, Sweetland's predicament seems to be

... a narrative dead-end, so to speak, except that the augmenting unreality of Sweetland's perceptions, especially after he secrets himself on the abandoned island, does not signify a loss, but a repossession, of self (Sanyal, 2014, n.p.).

Instead of dying alone on the island, Sweetland becomes part of the weave of life and death; a face in the ghostly crowd of ancestors that walks silently to the edge, where land meets sea, and wait for the light. Moses is absorbed into the mirror that is the island.

By exploring themes of attachment to place, and what Barry Lopez calls a "storied" or "reciprocal" relationship with the land, I have attempted to illustrate what happens to a man when confronted with leaving an island he knows as deeply as his own body and soul; and how the island reacts. In reacting, the island demonstrates its own agency and has shaped the identity of a people. As geographer Edward Relph (1976, p. 34) has written: "In short, people are their place and a place is its people, and however readily these may be separated in conceptual terms, in experience they are not easily differentiated." By examining how Sweetland the man has become inseparable from Sweetland the island - even as both of them have disappeared by the end of the novel - one can see the power of islandness and the strength of island identity: one becomes the other, mirrored, doubled. Indeed, the fact that the novel itself is called Sweetland suggests a three-way mirroring, heightening the idea that Sweetland the man is equated with Sweetland the island.

In the end, those who left Chance Cove may have moved on, but in real life many resettled Newfoundlanders go back to their islands and other abandoned outport communities in the summertime: they build cabins, they repair the grave markers and mow the grass and prune the bushes. They, like the ghosts of the ancestors who remain on the island, are haunted by their history: while they may have moved on, they do not forget.

\section{References}

Acorn, M. (2002). The edge of home: Milton Acorn from the island. Charlottetown, PE: Island Studies Press.

Baldacchino, G. (2013). Capital and port cities on small islands sallying forth beyond their walls: A Mediterranean exercise. Journal of Mediterranean Studies, 23(2), 137-151.

Bannister, J. (2003). The politics of cultural memory: Themes in the history of Newfoundland and Labrador in Canada, 1972-2003. In Collected Research Papers of the Royal Commission on Renewing and Strengthening our Place in Canada (pp. 119-166). St. John's NL: Government of Newfoundland and Labrador.

Bisonette, S. (2014). Crummey used real life stories in Sweetland, 05 November. Retrieved from http://www.parrysound.com/opinion-story/4961109-crummey-used-real-life-stories-insweetland/

Blackwood, D. (1979). Hauling Job Sturge's House. Etching and aquatint. Retrieved from http://fineartcollector.ca/a-guide-to-david-blackwoods-best-prints/ 
Cadigan S. T. (2009). Newfoundland and Labrador: A history. Toronto ON: University of Toronto Press.

Chafe, P. (2003). "The scuttlework of empire": a postcolonial reading of Wayne Johnston's The Colony of Unrequited Dreams." Newfoundland Studies, 19(2), 322-346.

Chafe, P. (2004). Lament for a notion: loss and the Beothuk in Michael Crummey's River Thieves. Essays on Canadian Writing, 82, 93-117.

Chafe, P. (2010). "Old Lost Land": Loss in Newfoundland historical fiction. In A. Cabajsky \& B. J. Grubisic (Eds.), National plots: Historical fiction and changing ideas of Canada (pp. 167-181). Waterloo, ON: Wilfrid Laurier University Press.

Conkling, P. (2007). On islanders and islandness. Geographical Review, 97(2), 191-201.

Crummey, M. (2004). Journey into a lost nation. In M. Crummey \& G. Locke (Eds.), Newfoundland: Journey into a lost nation (pp. 8-39). Toronto ON: McClelland and Stewart.

Crummey, M. (2014). Sweetland. Toronto ON: Doubleday.

Dalton, M. (1993). Allowing the light. St John's NL: Breakwater Books.

Dragland, S. (2012, January 30). Personal interview. St John's, NL.

Hay, P. (2006). A phenomenology of islands. Island Studies Journal, 8(2), 209-232.

Isaacs, J. (2015, January 5). The past is never dead: an interview with Michael Crummey, Retrieved from http://www.winnipegreview.com/wp/2015/01/the-past-is-never-deadan-interview-with-michael-crummey/

Johnson, B. (2001). Curator's essay. In S. Walden (Ed.), Unsettled, photographs by Scott Walden (pp. 9-15). St John's, NL: Art Gallery of Newfoundland and Labrador.

Johnston, W. (2006). The custodian of paradise. Toronto ON: Knopf Canada.

Johnston, W. (2009). The old lost land of Newfoundland: Family, memory, fiction, and myth. Edmonton, AB: NeWest Press.

Kelly, U. \& Yeoman, E. (Eds.) (2010). Despite this loss: Essays on culture, memory and identity in Newfoundland and Labrador. St. John's NL: ISER Books.

Lopez, B. (1996). A literature of place. U.S. Society and Values, August.

Lynch, K. (1960). Image of the city. Cambridge MA: MIT Press.

Maritime History Archive (2012). No great future: government sponsored resettlement in Newfoundland and Labrador since Confederation. Retrieved from http://www.mun.ca/mha/resettlement/rs_intro.php.

O'Flaherty, P. (1975). Looking backwards: the milieu of the old Newfoundland outports. Journal of Canadian Studies, 10(1), 3-9.

Relph, E. (1976). Place and placelessness. London: Pion.

Robinson, D. (2015, May 5). Interview: Michael Crummey on new book Sweetland. Retrieved from

http://www.scotsman.com/lifestyle/books/interview-michael-crummey-on-new-booksweetland-1-3761918.

Rogers, G. (1984). Floating houses: Poems. St. John's NL: Creative.

Sanyal, A. (2014, August 22). Michael Crummey's Sweetland is like a song of mourning. The Globe and Mail. Retrieved from http://www.theglobeandmail.com/arts/books-and-media/book-reviews/michaelcrummeys-sweetland-is-slow-circular-suitable-to-a-mans-contemplation-ofextinction/article20172450/. 


\section{Brinklow}

Sherren, R. (2014). Little Bay Islands in limbo as residents await word on relocation funds. Retrieved from http://www.cbc.ca/news/canada/newfoundland-labrador/little-bay-islands-in-limbo-asresidents-await-word-on-relocation-funds-1.2748198.

Steffler, J. (1985). The grey islands. Toronto ON: McClelland and Stewart.

Sugars, C. (2010). Gaelic phantoms: Geography, history, and ancestral inheritance in Kenneth Harvey's The town that forgot how to breathe and Michael Crummey's Galore. Newfoundland and Labrador Studies, 25(1), 7-36.

Tuan, Y-F. (1971). Geography, phenomenology, and the study of human nature. The Canadian Geographer, 15(3), 181-192.

Walden, S. (2001). Unsettled, photographs by Scott Walden. St John's NL: Art Gallery of Newfoundland and Labrador.

Weale, D. (1991). Islandness. Island Journal, 8, 81-82.

Wyile, H. (2011). Anne of Tim Horton's: Globalization and the reshaping of AtlanticCanadian literature. Waterloo, ON: Wilfrid Laurier University Press. 